\title{
Obituaries
}

\section{Sidney Crown}

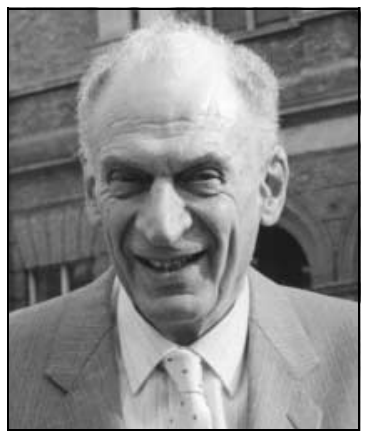

Formerly Consultant Psychiatrist at the London Hospital, Whitechapel

It is very difficult to write an obituary about Sidney Crown. The challenge to all obituarists is to summarise a long life in a few pithy, well-chosen words, but even a modern Shakespeare would find it impossible to summarise the life of Sidney.

When I first met him more than 40 years ago, I found it impossible to place him and, in the nosiness of youth, asked others to help me out. Eventually, a colleague suggested that he was 'someone from the old school'. I have pondered on this ever since and can only conclude that the school concerned was the Sidney Crown Academy of Excellence, which was notable in only having one pupil. At what other place would you be able to accommodate someone who had the insight of a sage, the visage of Hippocrates, the wit of a mischievous imp, the outspokenness of a prophet, the kindness of a saint, the interest of a polymath, and the physical stamina of an Emil Zátopek? One thing is certain: the Sidney Crown Academy of Excellence would have had to be in London. Samuel Johnson may never have tired of London, but not even he could have embraced it with quite the enthusiasm of Sidney Crown.

Sidney's life story showed all these characteristics. He first trained in psychology in South Africa after his family was evacuated there during the Second World War. He then trained as a psychiatrist at the Maudsley Hospital and won the Gaskell Gold Medal, and this, accompanied by Hans Eysenck and Aubrey Lewis as his supervisors, gave him a clear head start up the academic ladder. He joined the psychiatric department at the Middlesex Hospital shortly after it had been set up under the supervision of Professor Denis Hill, and was subsequently trained by Eliot Slater at 'Queen Square' (then the National Hospital for Nervous Diseases, now the Institute of Neurology). But this was not the conventional academic pathway to ivory-tower stardom that it appeared to be from the outside. While working for Eliot Slater, Sidney underwent full psychoanalysis - how he managed to incorporate both Freud and Slater into his daily thinking seems to me to be quite amazing - and then became a consultant at the London Hospital, Whitechapel. There he continued to practise both psychiatry and psychotherapy for four decades with the patients in the catchment area; and these were certainly not the more 'typical' patients who presented for psychoanalysis in some other parts of London. While at the Middlesex Hospital, Sidney developed (with Arthur Crisp) the Middlesex Hospital Questionnaire, which enjoyed great favour as both a personality and mental state assessment. In fact, it probably incorporated both and it was one of the most important precursors of what has followed in many different forms since.

Sidney edited the British Journal of Clinical Psychology (subsequently to become Psychology and Psychotherapy: Theory,
Research and Practice), and then joined the British Journal of Psychiatry as Book Review Editor. He held this position for the magnificent period of 46 years, which will probably represent an all-time record for anyone at the Royal College of Psychiatrists. He was assiduous, collaborative and innovative in this role and many will have benefited from his wise advice. The first review I ever sent in was in the style of James Joyce's Ulysses, full of strange sentences and neologisms. Sidney never beat about the bush and he wrote back smartly, 'Sorry, this won't work - we can't have it' - and he was right. Not for him the gentle oblique refusal, I got the straight uppercut. But he was basically the kindest of men. Many at the College will be familiar with his avuncular concern for all the staff there, quite irrespective of their status, and for his many runs on behalf of charities. He was a regular runner of the London Marathon from the date it first started and completed his last marathon at the age of 75. He also took great interest in his local charity, Fitzrovia Youth in Action, where he was a trustee since its inception. This again illustrates his continued concern with ordinary people in London, the real passion of his long career.

Sidney and his wife June, whom he met at the Middlesex Hospital as a medical student, were a happy and utterly devoted couple. They have three children, a consultant endocrinologist, a musician and a lawyer, showing a range of talents that reflects Sidney's own eclectic interests. The love and respect that all his family felt for Sidney was expressed movingly and evocatively by the readings and commemorative performances of his family at a service at the Royal College of Physicians in November last year.

And so for the final school report. 'I am very sorry to inform you that on 12 September 2009, at the age of 85, the only pupil from the Sidney Crown Academy of Excellence died suddenly. The school will now close and there is no plan to open it again.'

PeterTyrer

doi: 10.1192/pb.bp.110.029439

\section{David Hazell Clark}

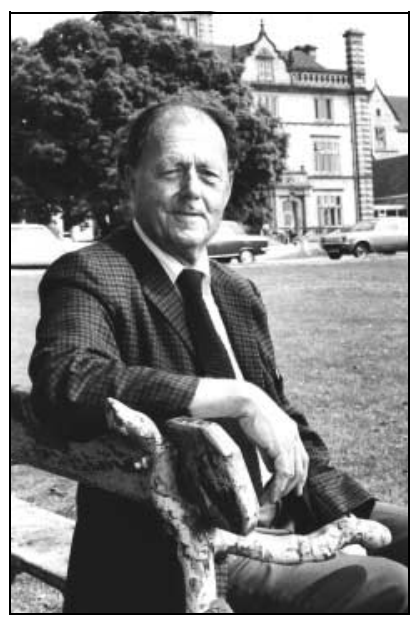

Formerly Physician Superintendent, Fulbourn Hospital, Cambridge

When I went to Fulbourn Hospital on psychiatric placement, Friday mornings began with a group session for all medical staff, students included. At my first meeting, the atmosphere was tense with criticism of the medical superintendent, David Clark. Never having seen David before and unable to recognise him, I found myself saying: 'It 
seems we have an emperor with no clothes'. There was a communal intake of breath and then a big man sitting ramrod straight in his chair let out a guffaw of laughter. It was David, of course, who had no problem at all about being taken to task by a callow student.

Months later, I had to be dragged away from my placement, convinced by what I had learnt from the emperor that psychiatry was what I wanted to practise for the rest of my life. It was an experience shared by generations of similar students who came to Fulbourn expecting little and left inspired by the ethos of humanity, group endeavour and therapeutic optimism that were the watchwords of the social psychiatry movement, of which David was the leader.

The irony was that David himself first came grudgingly to Fulbourn in 1953, soon after completing his psychiatry training under Sir David Henderson at Edinburgh, Professor Aubrey Lewis at the Maudsley, and S. H. Foulkes, the founder of group analysis. He arrived hoping for the interview experience alone and became to his surprise the youngest medical superintendent in the UK, in charge of 1000 patients, many of whom had been cooped up for years in a segregated, high-walled, oldstyle lunatic asylum. Within 5 years, there were no locked wards, male and female nurses were working for the first time together on the wards, in therapeutic workshops and industrial units, and the hospital and community were opening up to each other through half-way houses for patients and open days for visitors.

Although the diagnostic process remained important, it was to be set within social relationships between patients, between patients and staff, and within the hospital as a whole; the morale of the community mattered as much as individual treatment and, in turn, was key to the welfare of everyone involved. Out of David's practice came seminal books Administrative Therapy (1962, written on sabbatical at Stanford University, California, and bearing the influence of Carl Rogers and Erik Erikson, off whom he had the chance to bounce his ideas) and Social Therapy (1974, translated into seven languages), which became the 'bibles' of the Association of Therapeutic Communities, which he helped to found and was its first chairman.

Not surprisingly, David became a world-renowned figure, appointed as a World Health Organization's consultant who travelled through many countries, including Argentina, Poland, Peru and Japan, advising on the establishment and running of mental health services. But unlike contemporaries who would drift away to richer pickings in the USA, David always returned to the wards of Fulbourn Hospital, the scene of his greatest work, to whom he remained loyal until his retirement from the National Health Service in 1983.

In contrast, there were sides to David's life that few knew about. Born into a Quaker family on 28 August 1920 (his father, Alfred, was part of the Somerset shoemaking Clarks and became Professor of Pharmacology at University College London), he was appalled by the Hitler youth camps he was taken to when he was placed with a German family to improve his language skills at the age of 16 . He joined the Army at the outbreak of the Second World War and was parachuted into Germany to set up field ambulances. He freely told his friends and family that he did not expect to survive this most dangerous of missions; but did so. In the immediate aftermath of war, he became a medical officer in the transit camps for refugees, where he was deeply affected by what he saw of Belsen. He was sent to Sumatra to supervise the evacuation of 2000 Dutch citizens from a Japanese internment camp, and to Palestine, where he had his first experience of psychiatry. David was reticent about his war exploits but was persuaded in his retirement to set them down in Descent into Conflict (1995).

David married Mary Rose Harris, in 1946, by whom he had three children. After their divorce, he married Margaret Farrell, in 1983, herself fondly remembered as a teacher and practitioner in the Cambridge psychotherapy department. He is survived by Margaret, his siblings, children, five stepsons and countless 'children' of his inspirational practice. Over the latter part of his life, David saw great changes in psychiatry. There is a hint of sadness in his last book, The Story of a Mental Hospital: Fulbourn 1958-1983 (1996), for the passing of an era in which social and organic treatments sat happily alongside each other and which had enabled David, his colleagues and their patients to tear down some of the walls surrounding the hospital grounds with their bare hands. But his respect for the human being inside every diagnosis remains, whatever the approach.

Like his family, David rejected formal religion but Quaker values imbued the whole of his personal and professional life. He died on 29 March 2010, and when we gathered for his memorial service in the Friends House, in Cambridge, there were people from all walks of life who had come to voice their debt to a man who placed as much emphasis on patrolling the trackways of Suffolk as he did on the most prestigious award.

David, you were an emperor. It was just that, like all truly great men, you chose not to wear the finery.

Mike Shooter

doi: 10.1192/pb.bp.110.031765

\section{Harutiun Davidian}

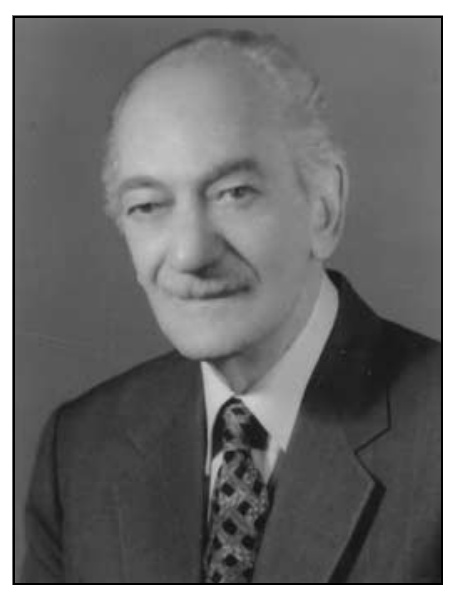

\section{Formerly Secretary and President, Iranian Psychiatric Association}

Professor Harutiun Davidian was born in 1924 in Tehran, Iran. After graduating from Alborz High School, he entered the Medical School of Tehran University and qualified in 1948. Pursuing his interest in psychiatry, he joined Professor Hossein Rezaee's firm at Pahlavi Hospital for specialty training. He then went to the Institute of Psychiatry in London for further experience and training and obtained his DPM in 1958.

On his return to Iran, he joined Professor Abdolhossein Mirsepassi's academic team at Roozbeh Hospital as an assistant professor, and was promoted to full professor in 1968. During his services at the Department of Psychiatry at the University of Tehran, he was head of the department on several occasions, as well as superintendent of Roozbeh psychiatric hospital, the first and most prestigious psychiatric hospital in Iran. 